\title{
漁港の生態系構造と生物現存量の推定
}

\section{Ecosystem Structure of a Fishing Port, and Presumption of a living Thing standing Stock}

\author{
三浦 浩 $^{1} \cdot$ 伊藤 靖 $^{2} \cdot$ 吉田 司 $^{3}$
}

\section{Hiroshi MIURA, Yasushi ITO and Tsukasa YOSHIDA}

\begin{abstract}
When fish and shellfishes live and a fishing port water area is regarded as a place (environmental base), a fishing port is a part of reef ecosystem which is located on the coast, has high calm nature compared with an oceanic region, and made the structure the subject. Moreover, it can realize as a part of network of the living space of fish and shellfishes centering on a childish fish. The quantitive evaluation examples from such a viewpoint are few. So, in this research, present condition grasp of the ecosystem structure in a fishing port and a living thing producing function was performed.
\end{abstract}

\section{1.はじめに}

漁港は係船や水揚げといった本来機能に加えて，水産 生物の生息場でもあり, 構造物やその周辺には多様な生 物の生息が確認されている。また，静穏域であることを 利用した種苗放流，中間育成等の幼稚魚の保護育成効果 や出荷調整のための蓄養等の副次機能を有している.さ らに，伊藤ら（2005）は，漁港における魚介類の生息空 間を餌場, 休息場, 隠れ場, 産卵場等に機能を分類した。

近年, 漁場整備事業は, 生態系全体の生産力の底上げ を目指し, 水産生物の動態，生活史に対応した良好な生 息環境空間を創出する新たな「水産環境整備」が提唱さ れた（水産庁，2013）。漁港においても，沿岸域の環境 基盤として捉え, 魚介類の生息場ネットワークの一部と して位置づけられている。しかし，こうした観点から漁 港を生物生産の場として定量的に評価した事例は僅かで ある。そこで, 本研究では, 漁港における環境特性から 類型化を行い, 生態系構造を把握した。さらに海区毎に 生物現存量の原単位化を行い，日本海北区について生物 現存量を推定した.

\section{2. 調査および研究の内容}

研究対象は, 日本国内の6海区（漁業センサス, 2010） から，各海区を代表する 2 ～ 3 漁港を抽出して，計 13 漁 港とした（図-1)。なお，広島県の沖浦漁港は，沖浦地区 と明石地区に分かれ，約 $1.5 \mathrm{~km}$ 離れた場所に立地するた め, 本研究では, 便宜的に沖浦地区を沖浦漁港, 明石地 区を明石漁港として区別した（以降，同様）。調査時期 は，2010 2012年の春季（5月）と夏季（9月）に海底地

\begin{tabular}{|c|c|c|}
\hline 1 & & (一財) 漁港漁場漁村総合研究所 \\
\hline 2 正会員 & & $\begin{array}{l}\text { 第2調査研究部 主任研究員 } \\
\text { (一財) 漁港漁場漁村総合研究所 } \\
\text { 第2調查研究部 部長 }\end{array}$ \\
\hline 3 & 学術博 & (株) シャトー海洋調査 環境調査部 部長 \\
\hline
\end{tabular}

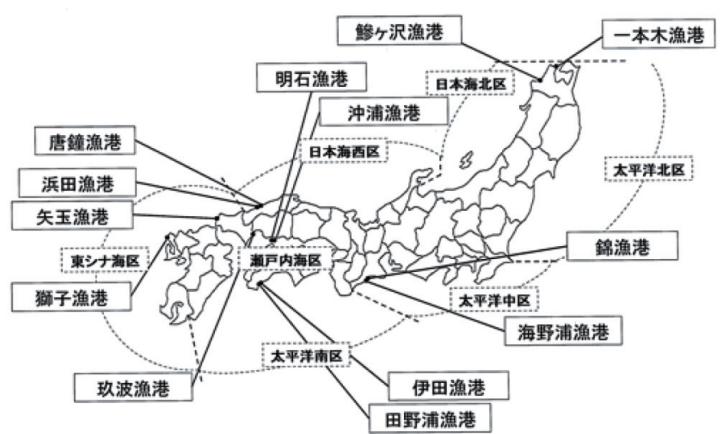

図-1 調査対象漁港

表-1 調査項目

\begin{tabular}{|c|c|c|}
\hline 大項目 & 小項目 & 方法 \\
\hline 海底地形 & & GPSソナー \\
\hline 流 況 & 流速·海水交換量 & ADCP \\
\hline \multirow[b]{2}{*}{ 水 質 } & 透明度·水温·塩分 $\cdot \mathrm{DO} \cdot \mathrm{Chl}-\mathrm{a}$ & 多項目水質計 \\
\hline & $\begin{array}{c}\text { COD·栄養塩類 } \\
(\mathrm{T}-\mathrm{N}, \mathrm{T}-\mathrm{P}, \mathrm{DIN} 、 \mathrm{DIP})\end{array}$ & 採水 \\
\hline 底 質 & 粒度組成,COD,T-S & グラブ式採泥器 \\
\hline \multirow{6}{*}{ 生 物 } & 植物プランクトン & 採水 \\
\hline & 海藻草類 & 目視観察·坪刈り $(0.5 \times 0.5 \mathrm{~m})$ \\
\hline & 動物プランクトン & 北原式定量ネット \\
\hline & 底生動物 & グラブ式採泥器 $\left(0.1 \mathrm{~m}^{2}\right)$ \\
\hline & 付着動物·葉上動物 & 坪刈り $(0.25 \times 0.25 \mathrm{~m})$ \\
\hline & 魚介類 & 目視観察·刺網等 \\
\hline
\end{tabular}

形, 流況, 水質, 底質, 生物に関する調査を実施した (表-1).

（1）漁港の類型化

漁港の立地環境の類型化を行うため, 春季（5月）調査 の結果から, 各漁港の沖合点（港外）における水質（水 温, Chl-a, 栄養塩類 $<$ T-N,T-P,DIN,DIP $>$ ), 底質 (COD,TS）の実測值に基づいて，地点間の標準化ユークリッド距 離を求めて, ウォード法によるクラスター解析を行った. 同様の方法で 13 漁港内の環境特性を類型化した. 


\section{（2）漁港の生態系構造}

\section{a) 栄養階級区分}

漁港水域に出現する生物を栄養段階別に基礎生産者 （植物プランクトン，海藻草類），一次消費者（動物プラ ンクトン，付着動物，底生動物，葉上動物)，二次消費 者 (全長 $10 \mathrm{~cm}$ 未満の稚魚や小型魚類), 三次消費者 (全 長 $10 \mathrm{~cm}$ 以上の肉食性魚類）に区分した。

\section{b）生息密度の算出}

生物現存量の算出べースとなる漁港に打ける生物毎の 生息密度は，以下の方法により算出した。

[基礎生産者]

植物プランクトン：多項目水質計により計測したChl-a

值（ $\mu \mathrm{g} / \mathrm{l} ）$ を鉛直積分したChl-a量 $\left(\mathrm{mg} / \mathrm{m}^{2}\right)$.

海藻草類：坪刈りにより採取した海藻草類の種毎の湿 重量 $\left(\mathrm{g} / \mathrm{m}^{2}\right)$.

\section{[一次消費者 $]$}

動物プランクトン：プランクトンネットの鉛直曳によ

り得られた単位体積当たりの個体数 (個体 $\left./ \mathrm{m}^{3}\right)$.

底生動物：グラブ式採泥器により採取した底生動物の 種毎の湿重量 $\left(\mathrm{g} / \mathrm{m}^{2}\right)$.

付着動物：基質に付着した生物をはぎ取り採取した種 毎の湿重量 $\left(\mathrm{g} / \mathrm{m}^{2}\right)$.

葉上動物：海藻と同時に採取した葉上動物の種毎の湿 重量 $\left(\mathrm{g} / \mathrm{m}^{2}\right)$.

なお，貝類等の重量に関しては，全重量から殸重量を 除いた身肉の重量を用いるため，中村ら（2003），押野 （2006）より，アサリは 0.44 , サルボウは 0.49 ，フジッボ は0.0694の換算係数を用いた。

[二次 ·三次消費者]

魚類：目視観測により確認された魚類の全長と個体数 を福田（1987）や漁獲調查から得られた魚類の全長-体重 (湿重量；g）曲線を用いて換算し，それぞれ観察面積や 漁獲面積から算出した $\left(\mathrm{g} / \mathrm{m}^{2}\right)$.

\section{c）炭素量への換算}

植物プランクトンの炭素量への換算係数は Riman et al. （1989）よりC（重量）/Chl-a（重量）=46を用いた。海 藻草類は金子ら (2007), 吉田ら (2001), 寺脇ら (2002) より分類群毎の炭素量への換算係数を整理した（表-2). 同様に，動物プランクトンは，城（1983）より（表-3）, 底生動物 ·付着動物 ·葉上動物は, 水産庁 ·全振協 （1991），押野（2006）に従った（表-4）。魚類は，水産 庁・全振協（1991）よりメバルの炭素量/湿重量 $=0.08$ を すべての魚種に用いた。

以上から単位面積 $\left(\mathrm{m}^{2}\right)$ 当たりの炭素量に換算して, 漁港水域別（港外，港口，港奥）の生物現存量を基礎生 産から高次消費者までの現存量の大きさに比例して描い た生態系ピラミッド (三角形) の形状で比較した。
表-2 海藻草類の湿重量から炭素量への換算係数

\begin{tabular}{l|l|c|c}
\hline \multicolumn{2}{|c|}{ 種名 } & 乾重量/湿重量 & 炭素量/乾重量 \\
\hline ワカメ & Undaria pinnatifida & 0.14 & 0.34 \\
\hline クロメ & Ecklonia kurome & 0.12 & 0.46 \\
\hline ホンダワラ & Sargassum fulvellum & 0.25 & 0.37 \\
\hline ヒジキ & Hizikia fusiformis & 0.20 & 0.34 \\
\hline アカモク & Sargassum horneri & 0.13 & 0.31 \\
\hline ノコギリモク & Sargassum serratifolium & 0.10 & 0.31 \\
\hline アマモ & Zostera marina & 0.14 & 0.32 \\
\hline
\end{tabular}

表-3 動物プランクトンの個体数から炭素量への換算係

\begin{tabular}{|c|c|c|c|c|}
\hline \multicolumn{3}{|c|}{ 動物分類群名 } & $\begin{array}{c}\text { 乾重量/個体 } \\
(\mu \mathrm{g} / \text { 個 }\end{array}$ & $\begin{array}{c}\text { 炭素量/墘重量 } \\
\left(\mathrm{mg} / \mathrm{m}^{2}\right) /\left(\mathrm{mg} / \mathrm{m}^{2}\right)\end{array}$ \\
\hline 環形動物門 & 多毛網 & Polychaeta & 29.1 & 0.35 \\
\hline \multirow{3}{*}{ 節足動物門 } & ミジンコ目 & Cladocera & 4.1 & 0.38 \\
\hline & カイアシ目 & Copepoda & 22.7 & 0.43 \\
\hline & 甲殼綱 & Other Crustacea & 119.0 & 0.33 \\
\hline \multirow{2}{*}{ 脊索動物門 } & オタマボヤ綱 & Appendicularia & 1.9 & 0.39 \\
\hline & タリア網 & Thaliacea & 30.8 & 0.30 \\
\hline 禍鞭毛動物門 & ヤコウチュウ属 & Noctiluca & 0.7 & 0.36 \\
\hline 刺胞動物門 & ヒドロ虫網 & Hydrozoa & 146.0 & 0.49 \\
\hline 毛顎動物門 & 現生矢中綱 & Sagittoidea & 190.0 & 0.40 \\
\hline
\end{tabular}

表-4 底生生物・付着動物・葉上動物の湿重量から炭素量へ の換算係数

\begin{tabular}{l|c|c}
\hline \multicolumn{1}{c|}{ 動物分類群 } & 降灰分乾重量/湿重量 & $\begin{array}{c}\text { 炭素量/乾重量 } \\
\left(\mathrm{mg} / \mathrm{m}^{2}\right) /\left(\mathrm{mg} / \mathrm{m}^{2}\right)\end{array}$ \\
\hline 多毛類 & 0.15 & 0.4 \\
\hline 軟体類：中型 & 0.05 & 0.4 \\
\hline 軟体類：小型 & 0.08 & 0.4 \\
\hline 甲款類 & 0.16 & 0.4 \\
\hline 棘皮類：ナマコ除く & 0.04 & 0.4 \\
\hline 輠皮類：ナマコ類 & 0.17 & 0.4 \\
\hline その他 & 0.17 & 0.4 \\
\hline
\end{tabular}

注) 軟体類は湿重量0.02g以下を小型,それ以外を中型とした。

\section{（3）漁港の生物生産機能}

\section{a) 原単位化}

漁港における生物生産機能を数量化するために，植物 プランクトン, 海藻草類, 動物プランクトン, 底生動物, 付着動物, 葉上動物, 魚類について, 分類群毎の漁港で の平均密度と分布範囲から漁港の全体量を集計し, 漁港 の水面面積で割り戻すことにより，原単位化を行った。

\section{b) 生物現存量の推定}

原単位化した数值から，生物現存量を推定するために, 日本海北区（青森県日本海側, 秋田県, 山形県, 新潟県, 富山県）に立地する漁港を対象とした。試算にあたって は，漁港一覧（水産庁，2012）より県別，漁港漁場整備 法に準ずる漁港種別（1～4種）に，それぞれ2～4漁港 を無作為抽出して, 航空写真より水面面積を計測し, 漁 港種別の平均值を求めた。 これらから，上記の県別・漁 港種別の漁港数を乗じて水面面積を算出し，原単位平均 （鮐ヶ沢漁港・一本木漁港）を乗じて生物現存量を推定 した。なお，外郭施設から $200 \mathrm{~m}$ の範囲までを漁港水域 とした. 
表-5 調查対象漁港の立地条件

\begin{tabular}{|c|c|c|c|c|c|c|c|c|c|}
\hline \multirow[b]{2}{*}{ 海区 } & \multirow[b]{2}{*}{ 漁港名 } & \multirow[b]{2}{*}{$\begin{array}{l}\text { 漁港 } \\
\text { 種別 }\end{array}$} & \multirow[b]{2}{*}{ 県 } & \multicolumn{6}{|c|}{ 立地条件 } \\
\hline & & & & $\begin{array}{l}\text { 海域 } \\
\text { 属性 }\end{array}$ & $\begin{array}{l}\text { 漁船 } \\
\text { 総数 } \\
\text { (隻) }\end{array}$ & \begin{tabular}{|l} 
属地 \\
陸揚量 \\
(トン)
\end{tabular} & 河川流入 & $\begin{array}{c}\text { 最大水深 } \\
(\mathrm{m})\end{array}$ & $\begin{array}{c}\text { 泊地面積 } \\
\left(\mathrm{m}^{2}\right)\end{array}$ \\
\hline \multirow{2}{*}{ 日本海北区 } & 一本木 & 1種 & 青森 & 外洋 & 204 & 128 & 港外東側 & 13.1 & 23,800 \\
\hline & 䱵ヶ沢 & 3種 & " & " & 159 & 1,252 & 港外東側 & 15.6 & 261,300 \\
\hline \multirow{2}{*}{ 日本海西区 } & 浜田 & 3種 & 島根 & 外洋 & 184 & 22,274 & 港奥南側 & 15.7 & 707,000 \\
\hline & 唐鐘 & 2種 & " & " & 65 & 105 & 港外西側 & 3.7 & 31,500 \\
\hline \multirow{2}{*}{ 太平洋中区 } & 錦 & 3 種 & 三重 & 外湾 & 198 & 3,453 & 港奥と港 & 14.4 & 239,000 \\
\hline & 海野浦 & 1種 & " & " & 107 & 320 & なし & 16.4 & 14,000 \\
\hline \multirow{3}{*}{ 瀬戸内海区 } & 玖波 & 2種 & 広島 & 内湾 & 50 & 2,910 & 港外西側 & 7.0 & 65,000 \\
\hline & 沖浦 & 2種 & " & 内湾 & 40 & 35 & なし & 16.0 & 36,000 \\
\hline & 明石 & 2種 & " & 水道部 & 40 & 35 & なし & 10.0 & 15,000 \\
\hline \multirow{2}{*}{ 太平洋南区 } & 伊田 & 1種 & 高知 & 外湾 & 55 & 196 & 港外北側 & 6.0 & 24,000 \\
\hline & 田野浦 & 2種 & " & " & 67 & 67 & なし & 7.0 & 94,000 \\
\hline \multirow{2}{*}{ 東シナ海区 } & 矢玉 & 2種 & 山口 & 外洋 & 111 & 197 & 港奥 & 12.0 & 41,000 \\
\hline & 獅子 & 1種 & 長崎 & " & 37 & 402 & 港奥 & 10.0 & 76,000 \\
\hline
\end{tabular}

注）漁船総数, 属地陸揚量はH21年漁港港勢調查による

\section{3. 調査結果及び考察}

\section{（1）漁港の立地条件と特徴}

現地調査結果を踏まえ, 対象漁港の立地条件を整理し た（表-5)。また，各漁港の生物・環境特性は以下のとお りである.

・一本木漁港（日本海北区，青森県）：津軽海峡に面 している．港外防波堤を中心にコンブ類が出現した。

一鰺ヶ沢漁港（日本海北区，青森県）：泊地面積が2 番目に大きく，陸揚量が多い。港内に排水口があり，水 質・底質環境に影響を及ほしている，大型海藻は少なか った。

・浜田漁港（日本海西区，島根県）：泊地面積・陸揚 量ともに最大である．港内に小河川が流れこみ，内湾的 環境から外洋的環境まで，様々な環境がみられた。構造 物には，クロメ，ホンダワラ類が出現した。

- 唐鐘漁港（日本海西区，島根県）；砂浜域の河口部 に立地する．港内はアマモが繁茂していた．水深が約 $4 \mathrm{~m}$ と調査漁港の中では最も浅かった。

・錦漁港（太平洋中区，三重県）：リアス式海岸の支 湾内に立地し, 泊地面積が大きく, 陸揚量は 2 番目に多 かった．港内に河川が流入している．港内はホンダワラ 類が出現した．かつて給仕養殖の実施筒所であり，その ためか，港内の底質が悪化していた。

・海野浦漁港（太平洋中区，三重県）：リアス式海岸 の支湾内に立地し，泊地面積が最少である．漁港東西に 排水口があり，漁港施設にはイセエビが出現した。

・㺵波漁港（瀬戸内海区，広島県）：広島湾奥の河口 域に立地する．港内に干潟やカキの加工施設がある。防 波堤にはクロメが出現した.

・沖浦漁港（瀬戸内海区，広島県）：安芸灘の水道部 に立地し，河川の流入はない。通水孔を取り付けた防波 堤があり，港内でマダイの中間育成を実施していた。

・明石漁港（瀬戸内海区，広島県）：安芸灘の水道部

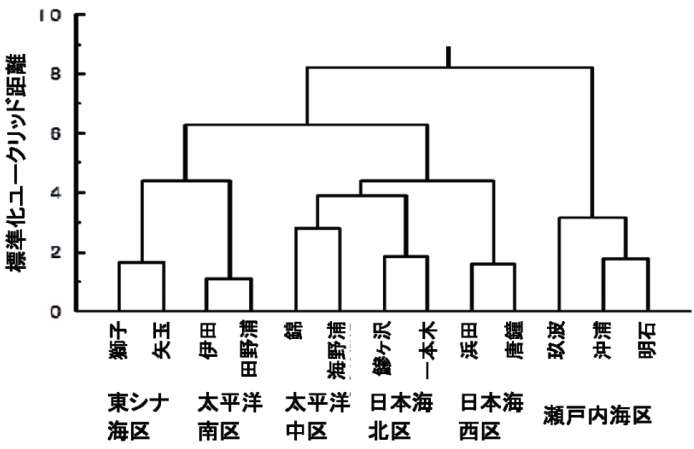

図-2 漁港の海域区分（水質，底質による)

表-6 類型化された漁港（海区）の水質・底質特性（5月）

\begin{tabular}{|c|c|c|c|c|c|c|c|c|}
\hline \multirow[b]{2}{*}{ 海 区 } & \multicolumn{6}{|c|}{ 水質 } & \multicolumn{2}{|c|}{ 底質 } \\
\hline & $\begin{array}{l}\text { 水温 } \\
\left({ }^{\circ} \mathrm{C}\right)\end{array}$ & $\begin{array}{l}\text { Chl-a } \\
(\mu \mathrm{g} / \mathrm{l})\end{array}$ & $\begin{array}{c}\mathrm{T}-\mathrm{N} \\
(\mathrm{mg} / \mathrm{l})\end{array}$ & $\begin{array}{c}\mathrm{T}-\mathrm{P} \\
(\mathrm{mg} / \mathrm{l})\end{array}$ & $\begin{array}{c}\mathrm{DIN} \\
(\mathrm{mg} / \mathrm{l})\end{array}$ & $\begin{array}{c}\mathrm{DIP} \\
(\mathrm{mg} / \mathrm{l})\end{array}$ & $\begin{array}{c}\mathrm{COD} \\
(\mathrm{mg} / \mathrm{g} \text { 乾泥 })\end{array}$ & $\begin{array}{c}\mathrm{T}-\mathrm{S} \\
(\mathrm{mg} / \mathrm{g} \text { 乾泥 }\end{array}$ \\
\hline 日本海北区 & $\begin{array}{c}12.0 \sim \\
13.6 \\
\end{array}$ & $\begin{array}{c}6.6 \sim \\
8.6 \\
\end{array}$ & $\begin{array}{c}0.17 \sim \\
0.24 \\
\end{array}$ & $\begin{array}{c}0.009 \sim \\
0.020 \\
\end{array}$ & $\begin{array}{c}0.005 \sim \\
0.050 \\
\end{array}$ & $\begin{array}{c}0.007 \sim \\
0.011 \\
\end{array}$ & $0.3 \sim 0.9$ & $<0.01$ \\
\hline 日本海西区 & $\begin{array}{c}16.6 \sim \\
16.8\end{array}$ & $\begin{array}{l}7.3 \sim \\
7.7\end{array}$ & $\begin{array}{c}0.18 \sim \\
0.20\end{array}$ & $\begin{array}{c}0.023 \sim \\
0.032\end{array}$ & $\begin{array}{c}0.097 \sim \\
0.123\end{array}$ & $\begin{array}{c}0.012 \sim \\
0.013\end{array}$ & $0.1 \sim 1.1$ & $<0.01$ \\
\hline 太平洋中区 & $\begin{array}{c}20.0 \sim \\
21.2\end{array}$ & $\begin{array}{c}7.7 \sim \\
9.0\end{array}$ & $\begin{array}{c}0.15 \sim \\
0.22\end{array}$ & $\begin{array}{c}0.018 \sim \\
0.030\end{array}$ & $\begin{array}{c}0.005 \sim \\
0.040\end{array}$ & $\begin{array}{c}0.007 \sim \\
0.012\end{array}$ & $1.4 \sim 4.8$ & $\begin{array}{c}<0.01 \sim \\
0.06\end{array}$ \\
\hline 太平洋南区 & $\begin{array}{c}21.0 \sim \\
21.1 \\
\end{array}$ & $\begin{array}{c}1.0 \sim \\
2.2 \\
\end{array}$ & $\begin{array}{c}0.07 \sim \\
0.12 \\
\end{array}$ & 0.023 & $\begin{array}{c}0.020 \sim \\
0.026 \\
\end{array}$ & $\begin{array}{c}0.015 \sim \\
0.016 \\
\end{array}$ & $0.7 \sim 1.6$ & $<0.01$ \\
\hline 東シナ海区 & $\begin{array}{c}18.3 \sim \\
18.5 \\
\end{array}$ & $\begin{array}{r}<0.5 \sim \\
1.6\end{array}$ & $\begin{array}{c}0.10 \sim \\
0.11 \\
\end{array}$ & $\begin{array}{c}0.011 \sim \\
0.012 \\
\end{array}$ & $\begin{array}{c}0.005 \sim \\
0.055 \\
\end{array}$ & $\begin{array}{c}0.005 \sim \\
0.008 \\
\end{array}$ & $0.8 \sim 1.3$ & $<0.01$ \\
\hline 瀬戸内海区 & $\begin{array}{c}12.4 \sim \\
14.9\end{array}$ & $\begin{array}{c}2.2 \sim \\
7.7\end{array}$ & $\begin{array}{c}0.07 \sim \\
0.09\end{array}$ & $\begin{array}{c}0.013 \sim \\
0.015\end{array}$ & 0.005 & $\begin{array}{c}0.004 \sim \\
0.010\end{array}$ & $3.7 \sim 6.2$ & $\begin{array}{c}0.04 \sim \\
0.09\end{array}$ \\
\hline
\end{tabular}

に立地し，河川の流入はない。防波堤の捨石部にはホン ダワラ類が繁茂していた。

- 伊田漁港（太平洋南区，高知県）：土佐湾の支湾内 に立地し，河川の流入がある。磯焼けがみられた。

- 田野浦漁港（太平洋南区，高知県）：土佐湾の支湾 内に立地し，河川の流入はない。防波堤にはクロメ，力 ジメ，ホンダワラ類が出現した。

- 矢玉漁港（東シナ海区, 山口県）：外洋に立地し, 河川の流入がある。防波堤にはホンダワラ類，クロメが 出現した。

・獅子漁港（東シナ海区，長崎県）：外洋に立地し， 河川の流入がある。磯焼けが進行していた。

\section{（2）漁港の類型化}

漁港水域を水質，底質に基づいて類型化を行った（図 2). 縦軸は要素同士の離れ具合（標準化ユークリッド距 離）を示す。その結果，最小ユニットとしては6海区に 対応した類型区分となり，これらに基づいて漁港の水 質・底質特性を整理した（表-6)。さらに，3分類すると， (1)東シナ海区・太平洋南区：高水温 $\left(18 \sim 21^{\circ} \mathrm{C}\right)$, 低栄 養塩（T-N : $\leqq 0.2 \mathrm{mg} / 1$ ，T-P： $\leqq 0.03 \mathrm{mg} / 1)$ ，(2)太平洋中 区・日本海北区・日本海西区：比較的高い $\mathrm{Chl}-\mathrm{a}$ 量 $(6.6$ $\sim 9.0 \mu \mathrm{g} / \mathrm{l})$ ，中程度の栄養塩（T-N : $\leqq 0.3 \mathrm{mg} / \mathrm{l}$, T-P : $\leqq$ $0.05 \mathrm{mg} / \mathrm{l}$ ），3瀬戸内海区：低栄養塩（T-N : $\leqq 0.2 \mathrm{mg} / 1$, $\mathrm{T}-\mathrm{P} ： \leqq 0.02 \mathrm{mg} / \mathrm{l}$ ），比較的高い底質分析值（COD：3.7 


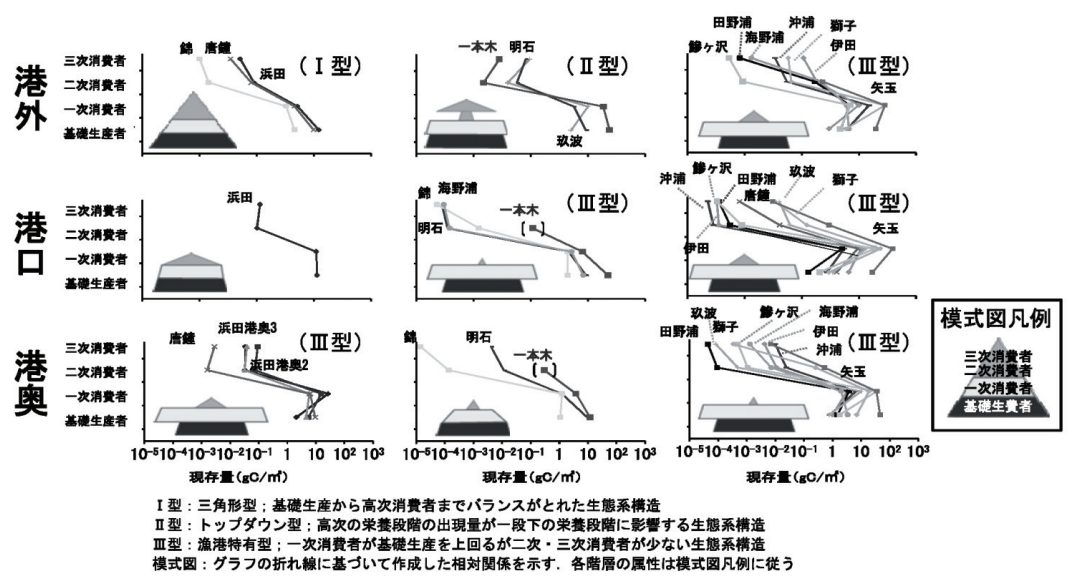

図-3 炭素含有量からみた漁港の生態系構造

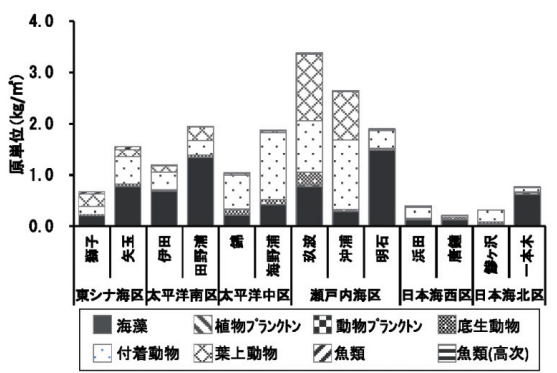

図-4 漁港の平均現存量の海域別比較

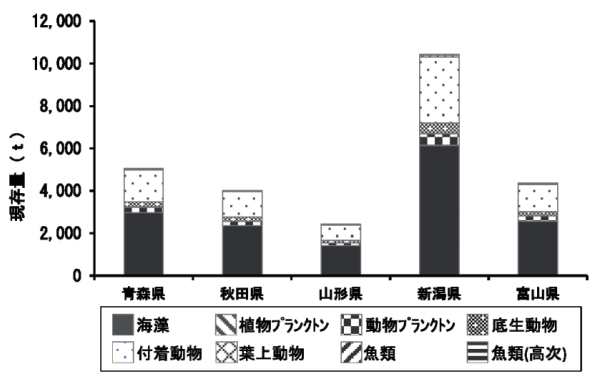

図-5 日本海北区の生物現存量の推定

〜 $6.2 \mathrm{mg} / \mathrm{g}$ 乾泥, T-S : $0.04 \sim 0.09 \mathrm{mg} / \mathrm{g}$ 乾泥）であった.

また同様の方法で各漁港水域内を類型化すると，いず れの漁港も港外，港口，港奥に区分された。これは，漁 港水域では, 港外から港奥に沿って環境勾配が変化して いることを示唆している.

以上より，漁港の類型化としては，漁港の立地する海 区スケールに区分され，漁業センサスによる区分との対 応がみられた。さらに漁港水域は，港外，港口，港奥に 細分された。従って，生物生産における海域特性の全国 的な区分として，海区に基づくことの妥当性が示された。

\section{（3）漁港の生態系構造}

栄養階級区分から漁港の特性をみると，基礎生産が最 も多く，裙野が広いバランスのとれた三角形型を示す漁 港水域（ I 型）は, 浜田漁港, 唐鐘漁港, 錦漁港のいず れも港外水域にみられた（図-3）。一本木漁港, 明石漁港, 玖波漁港の港外水域では, 三次消費者は二次消費者より も多く, 二次消費者に比べて一次消費者が突出して多く, 基礎生産者と同程度となるトップダウン型の生態系構造 （II 型）を示した。これら以外の多くの漁港では，港外 から港口, 港奥に沿って静穏度が高くなるにつれて, 構 造物を付着基盤とする付着動物を中心とした一次消費者 が突出して高くなり, 基礎生産を上回るが，二次・三次 消費者が少ない漁港特有の型（III型）の3タイプに区分 された. 従って多くの漁港水域では, いわゆる魚介類の 餌料供給過多な状況であることが明らかになった。

これらの要因として漁港内は，背後施設や流入河川，底 泥からの溶出等による栄養塩の供給と静穏度の増加に伴 い, 閉鎖性内湾と同様に富栄養的な環境となり, 動植物 プランクトンや底生動物が増加する。 また, 漁港水域は 構造物によって付着基盤が造成されることにより，一次 消費者である付着動物, 葉上動物等が増加し, 重量ベー スでは基礎生産を上回る。一方, 一次消費者の多く（重 量ベース）は，フジッボ類，カキ類やイガイ類等の二枚 貝類およびホヤ類等であり，これらは数種類の魚類を除 き飭料として利用できないため, 二次・三次消費者への 餌料供給が円滑に行われていないためと考えられる.

\section{（4）漁港の生物生産機能}

漁港の生物生息密度は, 瀬戸内海区が最も高く, 日本 海西区や日本海北区で低い傾向を示した（図-4）。瀬戸内 海区の内訳に着目すると海藻, 付着動物, 底生動物, 葉 上動物の生息密度が高かった。

瀬戸内海区の生物生息密度が高い理由としては，湿重 
量の大部分が一次消費者である付着動物, 底生動物, 葉 上動物によって占められており，これらの動物群はいず れも浮遊幼生期を有しており, 産卵水域から, 移動・分 散の過程において，陸域に囲まれた瀬戸内海区では，着 底に適した沿岸域の上部浅海帯（概ね $20 \mathrm{~m}$ 以浅）に移送 される機会が多いのに対し，その他海区では，着底不可 能な外洋に移送されて, 無効分散になる場合があること が一因と考えられる。

本研究で得られた漁港の原単位を用いて, 原単位が比 較的低位にあり, 生態系構造が理解しやすい日本海北区 を対象に海域全体に立地する漁港の生物現存量を試算し た (図-5)。この結果, 生物現存量の最少は山形県の 2,400tから, 最大は新潟県の $10,400 \mathrm{t}$ であり, 日本海北区 全体では，26,309t と推定された.

同様に，海区毎に立地する漁港の原単位を用いて，当 該海区の全漁港の水面面積を乗じることにより，海域全 体の生物現存量を数量化することが可能である. 一方で, 今回のデー夕は一例のみの結果であり, 今後, 同様のデ ー夕を集積し，精度向上に努める必要がある。また，現 存量から生産量を推定するためには，分類群に応じた $\mathrm{P} / \mathrm{B}$ 比を求めて各々に乗じることにより可能となる.

\section{4. まとめ}

漁港は, 漁船の休喤, 準備, 陸揚げ利用等に資する漁 業根拠地として沿岸の地形を改変して人工的に整備され た場所である。また，浅海域（概ね $15 \mathrm{~m}$ 以浅）に立地し ており, 藻場や干潟等の生産性の高い水深帯を包含して いる，さらに，漁港施設の設置自体に伴い，静稳度が高 くなるとともに，付着基盤の造成を行うことにより，岩 礁生態系の創出に寄与していると考えられる．魚介類等 の生息場として漁港の生態系構造と生物生産機能につい て以下に整理した。

○全国の漁港の立地環境を類型化した結果，最小ユニッ トとして海区スケールに区分され，3分類すると，(1) 東シナ海区・太平洋南区，(2)太平洋中区・日本海北 区・日本海西区，(3)瀬戸内海区に区分された.

○漁港水域の生態系構造は，3タイプが認められた.す なわち，I型：基礎生産から高次消費者までバランス がとれた水域，II 型：三次消費者と一次消費者が多く， 二次消費者と基礎生産者が少ないトップダウン型の水 域， III型：一次消費者が基礎生産を上回り，二次，三 次消費者が少ない水域であった。このうち I， II 型は 僅かであり，多くの漁港では，港外，港口，港奥に沿 って静穏度が高くなるにつれ， III型が多くなった。

○漁港の生物生息密度を求めて, 原単位化を行った。 そ の結果，瀬戸内海区が最も高く，日本海西区や日本海 北区で低い傾向を示した.
○漁港の原単位を用いて，海区毎に立地する全漁港の水 面面積を乗じることにより，海域全体の生物現存量が 推定され, 漁港を魚介類の棲み場 (環境基盤) として 捉えた場合の生物現存量を数量化する方法が示された.

謝辞：本研究は平成 $22 ２ 4$ 年度水産庁水産基盤整備調査 委託事業「水産環境整備推進技術開発」の一部をとりま とめたものであり，調査に際しては関係漁業協同組合の 協力の下実施した。また，本事業の検討委員会の委員各 位には,ご指導を賜った。ここに記して深謝申し上げる.

\section{参 考 文 献}

伊藤 靖 ·川合信也 - 押谷美由紀 · 間部本文 ·古村振一 . 小畑泰弘・三浦 浩 (2005): 漁港水域を利用した水産資 源増殖機能強化に関する考察, 海岸工学論文集, No. 54,pp. 1056-1060

伊藤 靖 · 三浦 浩 - 押谷美由紀 - 深瀬一之・吉永 聡 · 横山 純（2007）：漁港施設におけるイセエビの生息状況 に関する実態，海岸工学論文集，No. 54,pp. 1211-1215.

押野明夫 (2006): 新食材としてのフジッボ養殖生産の試み.フ ジツボ類の最新学, 日本付着生物学会編, 恒星社厚生閣, 東京,pp. 305-316.

金子健司 - 豊原哲彦 - 藤田種美 - 米田佳弘 - 中原紘之 (2007)：大阪湾の人工護岸上に形成された海藻群落の維持 と高密度に生息するウ二類の摂食活動, 日水誌, 73 巻, 3 号,pp. 443-453.

城 久・宇野史郎（1983）: 大阪湾における動物プランクトン の現存量とそれから見積られる生産量, 日本プランクト ン学会報, 30 巻, 1 号,pp. 44-51.

水産庁研究部研究科・(社) 全国沿岸漁業振興開発協会 （1991）: 平成 2 年度 沿岸漁場生産力評価技術高度化事業報 告書, $58 \mathrm{p}$.

水産庁漁港漁場整備部：漁港港勢平成元年～ 21 年（CD-ROM） 水産庁漁港整備部計画課：水産環境整備の推進（オンライン）, http://www.jfa.maff.go.jp/j/gyoko_gyozyo/g_thema/sub40.html, 参照2013-05-15.

水産庁漁港整備部計画課：漁港一覧（オンライン）, http://www.jfa.maff.go.jp/j/gyoko_gyozyo/g_zyoho_bako/gyok o_itiran/sub81.html, 参照2013-05-15.

寺脇利信 · 玉置 仁 ·西村真樹 · 吉川浩二 · 吉田吾郎 (2002) : 広島湾におけるアマモ草体中の炭素および窒素総 量,水研センター研報,第4号,pp. 25-32.

中村善治 · 深町孝子 · 真崎邦彦 · 関根幹男 · 三村信男 (2003): 有明海奥部のサルボウガイ漁場における炭素固定 量の評価, 海岸工学論文集,No. 50,pp. 1111-1115.

農林水産省大臣官房統計部（2010）：2008年漁業センサス第 1 巻海面漁業に関する統計（全国・大海区編），農林統計協 会, p. 9 .

福田富男（1987）: 各種魚類の相対成長式-体長, 全長, 体重の 関係-, 岡山水試報, pp. 167-170.

横山 純・伊藤 靖・主浦 浩・深瀬一之 (2008) : イセエビ の生息や増殖に資する漁港整備に関する考察，海洋開発 論文集，第24巻，pp. 795-800.

吉田吾朗・内村真之・吉川浩二・寺脇利信 (2001) : 広島湾に 生息する海藻類の炭素・窒素有量とその季節変化，瀬戸 内水研報, No. 3,pp. 53-61.

Rieman Bo, P. Simonsen and L. stensgard, (1989) The carbon chlorophyll content of phytoplankton from various nutrient regimes. T.plankton res., 11 (5) pp. 1037-1045. 